\title{
高校学生管理工作与思想政治教育协同育人研究
}

\author{
王宏伟 王佳羽
}

内蒙古自治区鄂尔多斯生态环境职业学院, 内蒙古 鄂尔多斯 017010

[摘要]在高校教育工作中, 学生管理是其中一项重要工作内容。而高校的思政教育这门专业课程, 旨在塑造学生良好的品德, 提高学生的素质, 也应该辅助高校学生管理工作, 让大学生具备更高的自主管理能力。文中就对于高校学生管理工作与思想 政治教育协同育人的相关内容作出具体研究, 以供参考。

[关键词]高校; 学生管理; 思想政治教育; 协同育人

DOI：10.33142/fme.v1i4.3342 中图分类号：G641 文献标识码：A

\section{Research on the Collaborative Education of College Student Management and Ideological and Political Education}

\author{
WANG Hongwei, WANG Jiayu
}

Inner Mongolia Ordos Ecological Environment Career Academy, Ordos, Inner Mongolia, 017010, China

\begin{abstract}
In higher education, student management is one of the most important tasks. The professional course of ideological and political education in colleges and universities aims to shape students' good moral character and improve their quality. It should also assist the management of college students and enable them to have higher self-management ability. This paper makes a specific research on the related content of the collaborative education of college student management and ideological and political education for reference.
\end{abstract}

Keywords: university; student management; ideological and political education; collaborative education

\section{引言}

推动高校的学生管理与思政教育齐头并进, 起到协同育人的作用, 这对于高校的教育来说, 是一个未来的发展趋 势。高校应该不断完善协同育人的相关机制, 在学生管理工作中, 将思政教育的主导作用进一步发挥出来, 营造一个 更加和谐的学生管理工作的氛围。

\section{1 高校学生管理工作与思想政治教育协同育人的优势}

\section{1 强化学生管理工作与思想政治教育体系化联动}

现阶段，随着信息技术的发展，已经进入了信息时代。在这样的时代背景之下，教育也出现了全新的的发展形式， 其中就具体体现在教育体系化联动。在高校的教育工作中, 学生管理工作与思政教育工作协同进行, 不仅能够强化学 生管理实践的紧密性, 还能够让思政课程的开展, 具备更高的实践综合能力。这样就能够让高校的教育, 充分迎合现 阶段学生的多元化需求, 提高高校管理的时效性, 推动教学实践的稳健发展。另外, 实现学生管理与思政教育体系化 联动, 能够进一步强化教师所发挥的教学管控力, 打破以往教育协作管理单一化的局面。而且教师还能对于教育管理 起到有效的沟通作用, 让较适合学生更好的参与和践行教育管理工作, 不断推动高校管理水平的提高, 促进思政教育 工作的有序进展。

\section{2 对于教育和管理资源实现合理配置}

在高校的教育工作开展过程中，长期面临着教育资源不足的问题。教育管理资源的分配不合理、不均匀，就会影 响高校教育管理工作的质量。通过高校学生管理和思政教育协同育人机制的确立, 能够进一步对于各项资源进行合理 配置, 推动管理工作和教育工作的规范化开展, 进一步确保教育管理的时效性, 而且能够为思政教育实践打下坚实的 基础。另外, 通过确立协同育人机制, 也能够协调管理工作与教育工作之间的矛盾冲突, 减少资源浪费的现象, 让各 种资源都能够在管理以及教育工作中充分利用，在此基础上进一步优化和完善教育和管理体系。

\section{3 对于高校教育管理应用实践成本的有效控制}

现阶段, 对于高校来说, 各种教育管理形式层出不穷, 教育管理的工作内容也呈现多样化的方向发展。多种教育 管理模式的并用就导致教育管理成本的不断增加, 不利于教育管理工作的持续性推进。通过学生管理工作与思政教育 的融合, 能够对于教育管理环节进行适当缩减, 利用思政教育对学生的行为起到规范的作用, 这样也能够取代传统的 学生管理模式, 推动学生自主管理能力的不断强化。而且这种自主管理的实践的推进, 也能在降低教育管理工作投入 
的同时, 提高教育管理水平。高校学生管理和思政教育工作齐头并进, 能够推动管理工作的进展更加系统化, 而且能 实现较低的成本投入。

\section{2 高校学生管理于思想政治教育协同育人的推进策略和路径}

现阶段, 随着高校学生管理和思政教育协同育人的不断应用, 在其中也具有一定的问题和困境。比如说对于教育 管理实践要求不到位, 思政教育的标准还有待完善; 高校现阶段实行的教育管理方式, 无法很好地契合思政教育形式; 学生管理与思政教育的协同育人体系还处于试点实践阶段, 没有形成体系化的规模。针对这些问题和困境, 就要采取 科学的策略, 通过合理的路径来推动学生管理和思政教育的协同育人的高效开展。

\section{1 强化学生的自主管理能力}

对于高校的学生管理工作来说, 学生的自主管理是未来发展的必然趋势。高校要将教育的优势充分发挥出来, 并 且把握住思政教育的特点, 不断提高学生的自主管理能力。利用思政教育课程所发挥的教育培养效果, 能够推动学生 自我管理意识的养成, 在日常的学习和生活中, 自觉规范各项行为。另外, 高校还要健全自主管理机制, 在思政教育 体系中, 适当的加入一定的自主管理权限, 这样就能够通过思政教育的影响, 不断带动学生进行自主管理的实践开展, 支持和帮助学生自主学习管理的高效进行。更好的发挥出学生管理与思政教育协同育人的实践应用作用, 让高校的管 理工作能够更好地满足现阶段的管理需求，让思政教育工作的开展，能够适应当前的教育目标要求。

\section{2 加强学生管理工作中的思政引导作用}

协同育人机制的推进，不仅要进一步完善高校的教育管理工作，同时在思政教育中，教师也要发挥好正面辅助的 引导作用。比如说进一步完善教育管理, 定期对于思政教师开展相关的管理培训, 这样就能够进一步引导思政教师发 挥管理工作的主导性作用, 而且还要切实掌握现阶段的学生管理目标, 在此基础上落实好教育引导工作。另外, 在进 行教育管理推进时, 也要以思政教育为着力点, 能够在思政课堂中融入各项管理细则, 让思政教育和学生管理工作更 好的结合在一起, 在思政教育的各项工作环节中, 都能够渗透进学生管理工作。这样就能够创造一个和谐的管理环境, 让教师与学生在其中能够养成积极的管理意识, 转变以往学生被动参与的管理局面, 提高学生自主管理能力和意识, 推动高校的协同育人工作实现全面发展。

\section{3 推动高校教育与管理实践的信息整合}

要想实现高校的学生管理和思政教育协同育人的不断推进和发展, 首先就要能够实现信息互通, 这是重要的前提 条件。高校要强化信息化的教育管理建设, 能够让学生管理与思政教育之间, 实现信息互通机制的建立, 让各项教育 管理资源得到有效共享。在掌握教学工作动向以及管理动态的基础上, 进行管理目标的制定, 确保其规范化, 这样就 能够进一步保证能够以管理和教育工作为中心, 开展科学性的规划。另外, 对于思政教育工作来说, 作为一种有效的 途径来塑造学生的核心价值观, 培养学生良好的人格品质, 也要在确保实现较高的教育质量的同时, 助力现阶段的学 生管理工作。让高校的思政教育工作不仅能够保障较高的专业教育质量, 还能够对于学生管理工作起到辅助作用。而 对于学生管理工作而言, 也要在学生所存在的管理问题, 在思政教育中进行及时的信息反馈, 这样也能够进一步强化 教师对于管理问题的解决能力, 这样就能够通过高校的思政教育, 合理的提高学生管理质量和水平。

\section{4 确立规范化的协同育人应用标准}

规范化的协同育人管理标准的确立, 能够让高校学生管理和思政教育工作统一工作步调, 让其能够实现管理和教 育的同步。首先, 在进行标准的制定时, 也要立足于学生管理长效化推进和思政教育系统化开展, 充分考虑到不同阶 段学生所体现出的不同的管理问题, 并且能够深究其问题的发生原因, 通过科学的管理策略对其进行解决。比如说, 对于现阶段的学生管理工作来说, 普遍存在着参与积极性较低, 或者是管理意识薄弱的问题。因此, 高校就要深入分 析问题的原因, 能够在当前的管理形式的基础之上, 进一步切实加强思想认识的教育, 让学生能够积极地参与到管理 工作中来。另外, 系统化的思政教育要注重完善管理体系, 能够通过思政教育为管理工作提供支持和帮助, 强化正面 引导作用, 进一步加强对于协同管理标准的制定, 让其能够充分的适应现阶段高校的学生教育和管理工作的各个方面。

\section{3 总结}

综上所述, 对于高校学生管理和思政教育协同育人的实践开展, 能够帮助学生实现自我管理意识的培养, 推动高 校教育管理能力的提高，为未来的管理工作和思政教育的推进，提供了全新的发展机遇。

\section{[参考文献]}

[1]任云凤. “三全育人”背景下高校辅导员协同育人的个案研究 [J]. 佳木斯职业学院学报, 2021, 37 (2) : 119-120.

[2]段翠英. 高校学生管理工作与思想政治教育协同育人研究 [J]. 湖北开放职业学院学报, 2020,33(23): 76-77.

[3] 徐瑞. 高校学生党建工作和大学生思想政治教育的协同育人模式构建 $[\mathrm{J}]$. 时代报告, 2020(7): 32-33.

作者简介: 王宏伟 (1968.8-) 女, 毕业院校: 内蒙古自治区广播电视大学, 所学专业: 政史, 当前就职单位: 内蒙古 自治区鄂尔多斯生态环境职业学院，职务：学生工作处副处长，职称级别：副教授。 